\title{
Reducing the hazardous effect of mineral nitrogen fertilizers on pepper production by using compost and compost extract in saline soil
}

\author{
Hafez Wafaa A. \\ Soil, Water and Environment Research Institute, Agriculture Research Center, Giza, Egypt
}

\begin{abstract}
A field experiment was carried out during two successive seasons; 2015/ 16 and 2016/ 17 at Gilbana village of Sahl El-Tina, North Sinia governorate, Egypt. The objective of this study was to evaluate the environmental risk of mineral nitrogen fertilizers on soil, water table and plant, compost was used as organic fertilizer as rate $(2.3$ and $4.6 \mathrm{Ton} / \mathrm{fed})\left(1 \mathrm{feddan}(\mathrm{fed})=4200 \mathrm{~m}^{2}=0.42\right.$ hectares $=1.038$ acres $)$, compost extract was added as a stimulating agent once every three weeks from transplanting for all treatment except control $(100 \%$ mineral fertilizer), which could give an economic yield of pepper, and avoid bad environmental effect of extra use of nitrogen mineral fertilizers. This experiment was designed in a Randomized Complete Block Design with three replicates. Two sources of nitrogen fertilizers are used in the experiment $\left(\left(\mathrm{NH}_{4}\right)_{2} \mathrm{SO}_{4}\right.$ and $\left.\mathrm{NO}_{3} \mathrm{NH}_{4}\right)$. The treatments were $\mathrm{T} 1-100 \%$ recommended dose of ammonium sulphate $(140 \mathrm{~kg} \mathrm{~N} / \mathrm{fed}), \mathrm{T} 2-75 \%$ of recommended dose of ammonium sulphate $(105 \mathrm{~kg} \mathrm{~N} / \mathrm{fed})$ and compost at the rate of $\left(2.3\right.$ ton fed $\left.^{-1}\right), \mathrm{T} 3-50 \%$ of recommended dose of ammonium sulphate + compost at the rate of (4.6 ton fed-1),T4 - 100\% Recommended dose of ammonium nitrate ( $140 \mathrm{~kg} \mathrm{~N} / \mathrm{fed}$ ), T5 - 75\% of recommended dose of ammonium nitrate $(105 \mathrm{~kg} \mathrm{~N} / \mathrm{fed})$ and compost at the rate of $\left(2.3 \mathrm{ton} \mathrm{fed}^{-1}\right)$ and $\mathrm{T} 6-50 \%$ of recommended dose of ammonium nitrate $(70 \mathrm{~kg} \mathrm{~N} / \mathrm{fed})+$ compost at the rate of $\left(4.6\right.$ ton $\left.\mathrm{fed}^{-1}\right)$. The results indicated that the addition of the fertilizer requirements as (Ammonium sulphate and ammonium nitrate) by $100 \%$ (140 kg N/fed) of each, produce (6.73 and 7.47) ton / fed of pepper production in the first season; respectively, in the second season, were (7.33 and 8.1) tons / fed, respectively. On the other hand, T3 (50\% ammonium sulphate (70 kg $\mathrm{N} / \mathrm{fed})+$ compost at the rate of $\left(4.6\right.$ ton $\left.\mathrm{fed}^{-1}\right)$ was the superior treatment for pepper production, and the lowest contamination of nitrates and nitrite in pepper fruit and loss in ground water.
\end{abstract}

Keywords: nitrogen fertilizer, Saline soil, water table, pepper productivity, leaching, losses, nitrate, nitrite, compost.

\footnotetext{
* Corresponding author:

E-mail address: wafaa.hafez28@yahoo.com
} 


\section{Introduction}

Nitrogen is a vital nutrient to enhance plant growth. This fact has motivated the intensive use of nitrogen-based fertilizers to boost up the productivity of crops in many regions of the world (Laftouhi et al., 2003). High fertilizer and manure use in intensive agriculture is one of the main sources of nutrient leaching losses to the environment, and the associated reduction in groundwater quality (Wolf et al., 2005). Tamm et al. (2009) mentioned that, once nitrogen fertilizers are applied to agricultural systems, the fertilizers are absorbed directly by plants or converted into other forms through the oxidation process. If nitrate is not absorbed by plant roots, it is carried away by runoff or leaches into the soil along with water. Also, Sina et al. (2012) reported that, some nitrogen fertilizers such as urea and ammonium nitrate have a high mobility and leaching potential. Excessive use of nitrogen fertilizers in agriculture has resulted in leaching of fertilizers and their derivatives below the root zone, contaminating groundwater. In general, Nitrate is also related to environmental problems including eutrophication of fresh waters and depletion of the ozone layer. Nitrates are very mobile in soil and have a high potential to migrate to ground water due to high solubility in water and weak retention by soil (U.S. Environmental Protection Agency, 1991; WHO, 2006). Nitrates and nitrites do not volatilize and therefore are likely to remain in water until consumed by plants or other organisms (U.S. Environmental
Protection Agency, 1991). Ammonium nitrate is taken up by bacteria, and nitrate degradation is fastest under anaerobic conditions (WHO, 2006). Nitrite is easily oxidized to nitrate, and nitrate is the more predominant compound detected in groundwater (U.S. Agency for Toxic Substances and Diseases Registry, 2001). It is believed that the major contribution of nitrate to groundwater is derived from the application of nitrogen fertilizer to agricultural lands. According to Guadagnin, et al. (2005), $\mathrm{NO}_{3}^{-}$is considered to be of low toxicity but when converted to $\mathrm{NO}_{2}^{-}$, it interacts with haemoglobin and affects the oxygen transport, leading to a condition known as methaemoglobin. When the human body takes high quantities of nitrate via drinking water and food meals, it may cause health disorders such as intestinal cancer and methemoglobinemia. Also, Koo and Connell (2006) mentioned that, elevated nitrate concentrations in surface water can cause qualitative changes in algal communities, for example, from diatoms to blue-green algae which is often toxic to humans. Plants normally take up $\mathrm{N}$ from the soil in the form of $\mathrm{NO}_{3}^{-}$, regardless its source However, little $\mathrm{NO}_{3}^{-}$accumulates in plants, when growth is normal, because the plant stems and leaves rapidly convert $\mathrm{NO}_{3}{ }^{-}$to amino acids and protein. Different environmental factors affect the concentration of NO3- in different vegetables. This balance can be disrupted so that the roots will take up NO3- faster than the plant can convert the $\mathrm{NO}^{-}$to protein. $\mathrm{NO}^{-}$accumulation is also dependent on the amount of $\mathrm{N}$-fertilizer and time of application (Guadagnin et al., 
2005). Direct determination of nitrate in soil is required for improving $\mathrm{N}$ application management and reducing environmental pollution (Robert, 2002). The identification of regions under the risk of $\mathrm{NO}_{3}$ - contamination is an important step in deciding on appropriate alternative management practices (Masetti et al., 2008). Cultivating edible crops with low nitrate content is very important. The U.S. Environmental Protection Agency (EPA) reference dose for nitrate is equivalent to about 7.0 $\mathrm{mg} \cdot \mathrm{kg}^{-1}$ body weight per day (Mensinga et al., 2003). Also, the Joint Expert Committee of the Food and Agriculture (JECFA) Organization of the United Nations/World Health Organization and the European Commission (EC) Scientific Committee on Food have also set an acceptable daily intake for nitrate $\begin{array}{llll}\text { of } & 0 & -3.7 & \mathrm{mg} \cdot \mathrm{kg}-1 \\ \text { body weight }\end{array}$ (Santamaria, 2006). Soil salinity is one of the most important problems in arid and semi-arid regions of the world reducing the yield crops. Sina et al. (2012) observed that, measurement of NO3-N from drained water, ammonium sulphate has the least and ammonium nitrate has the highest contamination potential. Therefore application of nitrogen in the form of ammonium sulphate is more effective to be used in saline soils (under leaching) as compared to urea and ammonium nitrate. Compost defined as the stabilized and sanitized product of composting of organic residues, which is compatible and beneficial to soil properties (Physical, chemical, and biological fertility) plant growth (Diaz et al., 2007). Plosek et al. (2013) reported that, compost can be used not only to increase soil fertility but also to stop the leaching of mineral nitrogen. The data obtained by Jakub Elbl et al. (2014) demonstrate that, the highest decrease of mineral nitrogen leaching was observed by the applications of soluble humic substances and compost to soil samples as compared with same doses of mineral nitrogen fertilizers. Abdelbasset et al. (2009) stated that application of compost may be a very useful tool for ameliorating severely salt-affected areas through the establishment of plant cover, including deep-rooted crops. Pepper (Capsicum annuum L.) is one of the three important solanaceous vegetable crops grown for their fruits, which are consumed, either fresh or dried. It is classified as moderately sensitive to salinity, and some adverse effects of salinity have been reported by VillaCastorena et al. (2003). Marco et al. (2011) found that, an apparent increase in salt tolerance was noted when Chile pepper plants (Capsicum annuиm L.) were fertilized with organic-N source compared to that of inorganic- $\mathrm{N}$ one and the absolute yield of pepper fertilized with the high $\mathrm{N}$-organic rate was superior. Pepper is popular vegetable crops and is considered as $\mathrm{N}$ - consumer differs widely in their nitrogen needs and in the pattern of uptake over the growing season. Fruiting crops such as pepper require relatively little nitrogen until flowering begins, and then increase their nitrogen uptake, reaching a peak during fruit set and early fruit bulking period. As fruits mature, $\mathrm{N}$ demand drops again. Pepper needs different amount of nitrogen fertilization through its development stage, in vegetative growth 
(900 - 1200), early flower/fruit (700 1000) and Fruit bulking (700 - 1000) $\mathrm{NO}_{3}-\mathrm{N}(\mathrm{ppm})$.

\section{Materials and methods}

\subsection{Location}

The experiment was carried out in two seasons 2015/16 and 2016/17 at a private farm, Gilbana village, Quntra Sharke located at the semiarid region of North Sinai governorate, Egypt. Sahl El-Tina lies in the north-western Mediterranean coast of Sinai, between $32^{\circ}{ }_{-} 35^{\circ}$ and $32^{\circ}$ $45^{\circ} \mathrm{E}$ and $31^{0}{ }_{-} 25^{\circ} \mathrm{N}$ (Kaiser, 2009). This area is irrigated with El-Salam canal water (Nile water mixed with agriculture drainage water by (1:1).

\subsection{Treatments and experimental design}

The field experiment was carried out to evaluate the environmental risk of mineral nitrogen fertilizers on soil, ground water and plant. Pepper (Marcony, Capsicum annuum L.) seeds were sown in the first week of September during both seasons. The seedlings were transplanted 30 days after sowing. Transplanting was done in rows with spacing of $25 \mathrm{~cm}$ in the row. Chemical fertilizers were added after a week from transplanting however compost was added during preparing the soil. Liquid compost was sprayed as a stimulating agent once every three weeks for all treatments except control (100\% mineral fertilizer). Treatments were defined according to the different levels of mineral nitrogen fertilizer ammonium sulphate (Amm S $20.5 \quad \% \quad \mathrm{~N}$ ) and ammonium nitrate $\left(\mathrm{Amm} \mathrm{NO}_{3} 33 \% \mathrm{~N}\right)$, Compost was used as organic fertilizer as rate (2.3 and 4.6 Ton/fed) (1 feddan (fed) $=4200 \mathrm{~m}^{2}=0.42$ hectares $=1.038$ acres $)$. Compost extract was added as a stimulating agent. All treatments received phosphorus fertilizer (Superphosphate $15.5 \% \quad \mathrm{P}_{2} \mathrm{O}_{5}$ ) and potassium fertilizer (potassium sulfate 48 $\% \mathrm{~K}_{2} \mathrm{O}$ ) at the recommended doses for grown pepper crop. The experimental plot area was $60 \mathrm{~m}^{2}(6 \times 10 \mathrm{~m})$ in a complete randomized block design with three replicates. The treatments were as follows:

- T1: Recommended dose of ammonium sulphate ( $140 \mathrm{~kg} \mathrm{~N} / \mathrm{fed})$.

- $\quad T 2: 75 \%$ of the recommended dose of ammonium sulphate $(105 \mathrm{~kg} \mathrm{~N} / \mathrm{fed})$ plus compost at the rate of (2.3 ton / fed).

- T3: $50 \%$ of the recommended dosage of ammonium sulphate $(70 \mathrm{~kg} \mathrm{~N} / \mathrm{fed})$ plus compost at the rate of (4.6 ton / fed).

- T4: Recommended dose of ammonium nitrate (140 kg N/fed).

- $\quad T 5: 75 \%$ of the recommended dose of ammonium nitrate $(105 \mathrm{~kg} \mathrm{~N} / \mathrm{fed})$ plus compost at the rate of ( 2.3 ton / fed).

- T6: T6 - 50\% of the recommended dose of ammonium nitrate $(70 \mathrm{~kg}$ $\mathrm{N} / f e d)$ plus compost at the rate of (4.6 ton / fed).

- Compost extract was sprayed once every three weeks for all treatments except control $(100 \%$ mineral fertilizer) and after each collection fruit in T2, T3, T5 and T6 treatments 
while $\mathrm{T} 1$ and $\mathrm{T} 4$ treatments received activation recommended dose of nitrogen mineral fertilizer.

\subsection{Analytical methods}

\subsubsection{Soil analysis}

Soil samples were collected at depth (0$30,30-60$ and 60-90) from the study area, during planting and also from each experimental plot after plant harvesting at soil depth (0-30). The samples were air dried ground, sieved (2 mm mesh) and kept for analysis. The physical and chemical properties were done according to Piper (1950) and Page et al. (1982). Nitrogen $\left(\mathrm{NO}_{3}-\mathrm{N}\right.$ and $\left.\mathrm{NH}_{4}-\mathrm{N}\right)$ in Surface soil samples $(0-30 \mathrm{~cm})$ were determined by micro Keldahl, according to Jackson
(1967). Phosphorus was determined Spectrophotometrcally using ammonium molybdate/ stannous chloride method according to Chapman and Pratt (1978). Potassium was determined by a flame photometer, according to Page et al. (1982). Available macro and micronutrients were described according to the methods of Cottenie et al. (1982). The obtained results were presented in Table (1). The compost analyses were done according to the standard methods described by Brunner and Wasmer (1978), and some chemical characteristics of the compost and compost extract are presented in Tables (2). A rapid qualitative test for nitrates and nitrite in soil was done according to Bray (1945) and Nelson et al. (1954) with modified.

Table (1): Particle size distribution and chemical properties of the initial soil sample before planting in two seasons.

\begin{tabular}{|c|c|c|c|c|c|c|c|c|}
\hline $\begin{array}{c}\text { Coarse sand } \\
(\%)\end{array}$ & Fine sand $(\%)$ & $\begin{array}{l}\text { Silt } \\
(\%)\end{array}$ & Clay $(\%)$ & \multicolumn{2}{|c|}{ Texture } & \multicolumn{2}{|c|}{ O.M $\left(\mathrm{g} \mathrm{kg}^{-1}\right)$} & $\mathrm{CaCO}_{3}\left(\mathrm{~g} \mathrm{~kg}^{-1}\right)$ \\
\hline 4.16 & 62.84 & 7.63 & 25.37 & \multicolumn{2}{|c|}{ Sandy clay } & \multicolumn{2}{|c|}{3.7} & 10.48 \\
\hline \multirow{2}{*}{$\mathrm{pH}(1: 2: 5)$} & \multirow{2}{*}{$\begin{array}{l}\mathrm{EC}\left(\mathrm{dsm}^{-1}\right) \text { in } \\
\text { soil paste }\end{array}$} & \multicolumn{4}{|c|}{ Cations $\left(\mathrm{mmolc} \mathrm{L}^{-1}\right)$} & \multicolumn{3}{|c|}{ Anions $\left(\mathrm{mmolc} \mathrm{L}^{-1}\right)$} \\
\hline & & $\mathrm{Ca}^{++}$ & $\mathrm{Mg}^{++}$ & $\mathrm{Na}^{+}$ & $\mathrm{K}^{+}$ & $\mathrm{HCO}_{3}^{-}$ & $\mathrm{Cl}^{-}$ & $\mathrm{SO}_{4}^{-}$ \\
\hline \multicolumn{9}{|c|}{ First season } \\
\hline 8.1 & 9.9 & 28.38 & 26.22 & 53.88 & 1.31 & 1.51 & 68.32 & 39.96 \\
\hline \multicolumn{9}{|c|}{ Second season } \\
\hline 8.05 & 10.8 & 28.08 & 25.52 & 52.88 & 1.52 & 1.82 & 65.32 & 40.86 \\
\hline
\end{tabular}

\subsubsection{Plant analysis}

Total weight of pepper fruits in each treatment was recorded every three weeks and then the total yield as ton/fed. was calculated. Samples of dry pepper fruit (dried at $70{ }^{\circ} \mathrm{C}$ for 48 hours). The collected fresh samples of pepper fruit was kept in the refrigerator for analysis nitrates and nitrite. A rapid qualitative test for nitrates and nitrite in plant tissues was done according to Bray (1945) and modified by Nelson et al. (1954). The obtained data were statistically analyzed according to Snedecor and Cohran (1979). 
Table (2): Compost and compost extract analysis.

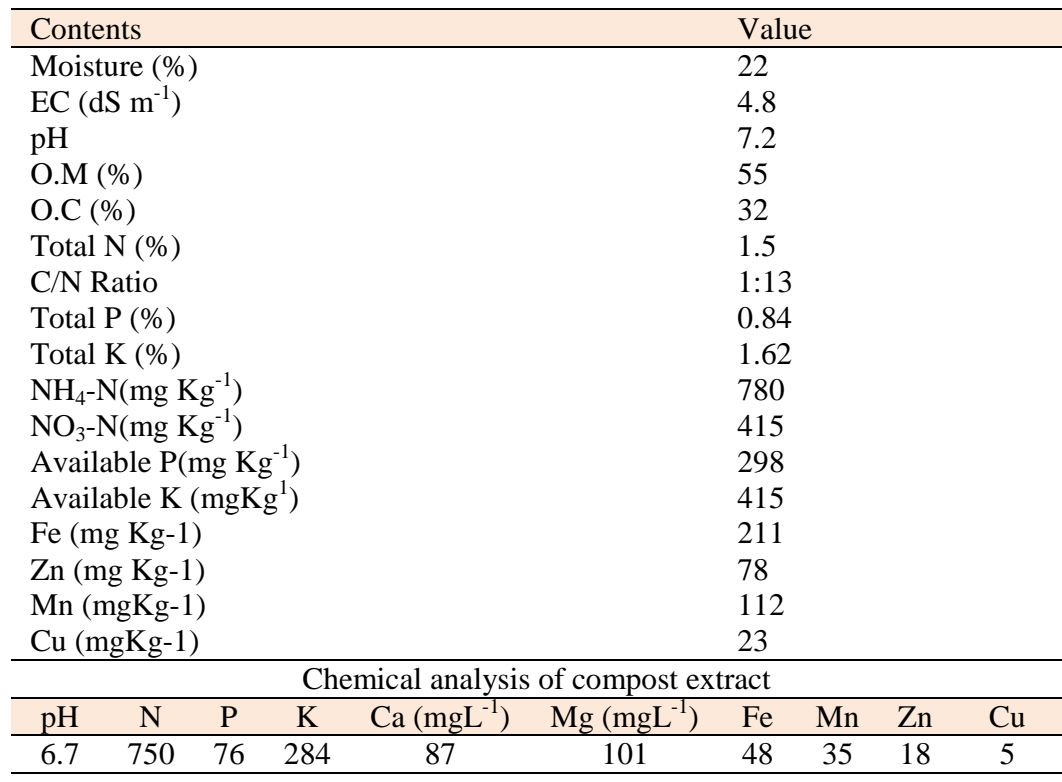

\subsubsection{Water analysis}

Observation wells casings were constructed of 2" PVC pipe approximately $1.5 \mathrm{~m}$ long according to $\mathrm{El}$ fayoumy et al. (2000). The collected water table samples were done before irrigation and every four days after each irrigation and kept for analysis. The chemical properties were done according to Piper (1950), Black (1965) and Page et al. (1982). A rapid qualitative test for nitrates in ground water given by Bray (1945) was modified by Nelson et al. (1954). Transfer factors (TF) for nitrate or nitrite from soils to vegetables; Transfer factor (TF) is the ratio of the concentration of nitrate or nitrite in a plant to the concentration of nitrate or nitrite in soil. TF for nitrate and nitrite were computed based on the method described by Harrison and Chirgawi
(1989), according to the following formula: $\mathrm{TF}=\mathrm{Ps}\left(\mu \mathrm{gg}^{-1} \mathrm{dry} \mathrm{wt}\right) / \mathrm{St}\left(\mu \mathrm{gg}^{-1}\right.$ dry wt) (Raiswell and Liss, 1982), Where Ps is the plant nitrate or nitrite content originating from the soil and $\mathrm{St}$ is the total nitrate or nitrite contents in the soil.

\section{Results and Discussion}

3.1 Effect of nitrogen fertilizers on $\mathrm{NO}_{3-}$ $\mathrm{N}$ and $\mathrm{NH}_{4} \mathrm{~N}$ concentration leached from a saline

\subsubsection{Water table (ground water)}

\subsubsection{1 $\mathrm{NO}_{3}-\mathrm{N}$}

The concentrations of $\mathrm{NO}_{3}-\mathrm{N}$ in water table before and after irrigation are shown in Table (3). The highest value of 
$\mathrm{NO}_{3}-\mathrm{N}$ concentration in water table was recorded in case of applying the recommended dose of ammonium sulphate (140 kg N/fed) after irrigation where it reached 93.27 and $97.97 \mathrm{mg} / \mathrm{l}$ in the first and second season, respectively. While in the 2nd and 3rd treatments they reached 85.07 and $55.83 \mathrm{mg} / \mathrm{l}$ for the corresponding seasons. In general, the losses of $\mathrm{NO}_{3}-\mathrm{N}$ concentration could arrange in descending order of $1^{\text {st }}>2^{\text {nd }}>$ $3^{\text {rd }}$ treatment this might be due to the intensive nitrogen fertilizer applications in 1st treatment and nitrate leaching throughout the soil layers. The successive uses of $\mathrm{N}$-fertilizers in the studied area reflected high nitrate concentration in water table. Therefore, the estriction degree on the reuse of such water for irrigation is slight to moderate according to the guidelines of Ayers and Westcot (1985), as it could create human health and severe problems in long run uses Garwood et al. (1999). Moreover, the addition of recommended dose of ammonium nitrate $(140 \mathrm{~kg} \quad \mathrm{~N} / \mathrm{fed})$ resulted in the highest value of $\mathrm{NO}_{3}{ }^{-} \mathrm{N}$ concentration in water table as it reached
115.8 and $101.1 \mathrm{mg} / 1$ in the first and second season after irrigation, respectively. Generally, the average $\mathrm{NO}_{3-}$ $\mathrm{N}$ losses in water table after addition of ammonium nitrate $\left(\begin{array}{llll}140 & \mathrm{~kg} & \mathrm{~N} / \mathrm{fed}\end{array}\right)$ fertilizer in the first and second season were higher than that in $2^{\text {nd }}$ and $3^{\text {rd }}$ treatments according to the level of ammonium nitrate application for instance, in case of the $2^{\text {nd }}$ and $3^{\text {rd }}$ treatments they reached 95.7 and 56.33 then 73.23 and $42 \mathrm{mg} / 1$ in the first and second season, respectively. The concentration of $\mathrm{NO}_{3}-\mathrm{N}$ in ground water after irrigation was higher than that before irrigation. This might be due to that $\mathrm{NO}_{3}-\mathrm{N}$ concentration associated with wells of water table levels close to surface. Water table pollution caused by leaching of $\mathrm{NO}_{3}-\mathrm{N}$ from agricultural systems has caused public concerns for decades Ersahin et al. (2001). Rationalizing fertilizer application is an important issue for sustainable agriculture because it can reduce the negative effects of farming on the surrounding environment Zebarth et al. (2009).

Table (3): The mean values of $\mathrm{NO}_{3}$ - and $\mathrm{NH}_{4}$ concentration in water table during two seasons.

\begin{tabular}{|c|c|c|c|c|c|c|c|c|c|}
\hline \multirow[t]{2}{*}{ Treatments } & \multirow{2}{*}{$\begin{array}{l}\text { Rate } \\
\text { Seasons }\end{array}$} & \multicolumn{2}{|c|}{$\begin{array}{c}\mathrm{NO}_{3} \mathrm{PPM} \\
\text { before irrigation }\end{array}$} & \multicolumn{2}{|c|}{$\begin{array}{c}\mathrm{NO}_{3} \mathrm{PPM} \\
\text { after irrigation }\end{array}$} & \multicolumn{2}{|c|}{$\begin{array}{c}\mathrm{NH}_{4} \mathrm{PPM} \\
\text { before irrigation }\end{array}$} & \multicolumn{2}{|c|}{$\begin{array}{c}\mathrm{NH}_{4} \mathrm{PPM} \\
\text { after irrigation }\end{array}$} \\
\hline & & $1^{\mathrm{st}}$ & $2^{\text {nd }}$ & $1^{\text {st }}$ & $2^{\text {nd }}$ & $1^{\mathrm{st}}$ & $2^{\text {nd }}$ & $1^{\text {st }}$ & $2^{\text {nd }}$ \\
\hline \multirow{3}{*}{$\left(\mathrm{NH}_{4}\right)_{2} \mathrm{SO}_{4}$} & $100 \%$ mineral & 62.8 & 53.83 & 93.27 & 97.97 & 53.47 & 19.8 & 71.2 & 64.1 \\
\hline & $75 \% \min +2.3$ & 45.47 & 47.77 & 85.07 & 55.83 & 44.83 & 14.77 & 65.33 & 41.87 \\
\hline & $50 \% \min +4.6$ & 14.93 & 29.63 & 71.93 & 42.63 & 33.77 & 9.8 & 41.83 & 27.87 \\
\hline \multirow{3}{*}{$\mathrm{NH}_{4} \mathrm{NO}_{3}$} & $100 \%$ mineral & 72.73 & 77.23 & 115.8 & 101.1 & 68.1 & 23.77 & 80.47 & 76.63 \\
\hline & $75 \% \min +2.3$ & 39.0 & 42.0 & 95.7 & 56.33 & 49.83 & 20.80 & 68.23 & 56.73 \\
\hline & $50 \% \min +4.6$ & 11.93 & 29.8 & 73.23 & 42.0 & 39.83 & 11.93 & 44.73 & 36.17 \\
\hline \multicolumn{2}{|c|}{ L.S.D at $0.05 \%$} & 1.137 & 0.5992 & 0.5992 & 0.5225 & 0.5918 & 0.5842 & 0.6869 & 0.1887 \\
\hline
\end{tabular}




\subsubsection{2 $\mathrm{NH}_{4} \mathrm{~N}$}

The concentrations of $\mathrm{NH}_{4}-\mathrm{N}(\mathrm{mg} / \mathrm{l})$ in the water table using the two nitrogen fertilizers sources before and after irrigation are shown in table (3). These results indicate that $\mathrm{NH}_{4}-\mathrm{N}$ concentrations in water table were higher in case of applying the recommended dose of ammonium nitrate or ammonium sulphate (140 kg N/fed) in both seasons than that in $2^{\text {nd }}$ and $3^{\text {rd }}$ treatments. This result could be attributed to the lower amounts of nitrogen fertilizer added at the $2^{\text {nd }}$ and $3^{\text {rd }}$ treatment than at the $1^{\text {st }}$ one. On the other hand, the highest values of $\mathrm{NH}_{4}-\mathrm{N}$ concentration were 80.47 and $76.63 \mathrm{mg} / 1$ in the first and second season, respectively in case of applying the recommended dose. Generally, the average $\mathrm{NH}_{4}-\mathrm{N}$ concentration in water table after addition of ammonium nitrate $(140 \mathrm{~kg}$ $\mathrm{N} /$ fed) fertilizer in both seasons were higher than that in $2^{\text {nd }}$ and $3^{\text {rd }}$ treatments. On the other hand, in case of the $2^{\text {nd }}$ treatment they reached 68.23 and 56.73 $\mathrm{mg} / \mathrm{l}$ in both season, respectively. While after the $3^{\text {rd }}$ treatment they were 44.73 and $36.17 \mathrm{mg} / \mathrm{l}$ in both seasons, respectively. While the average $\mathrm{NH}_{4}-\mathrm{N}$ concentration of ground water after addition of ammonium sulphate (140 kg $\mathrm{N} / \mathrm{fed}$ ) fertilizer in both season were higher than the average concentration of $\mathrm{NH}_{4}-\mathrm{N}$ in $2^{\text {nd }}$ and $3^{\text {rd }}$ treatments as there were $65.33,41.87,41.83$ and $27.87 \mathrm{mg} / 1$ in both seasons, respectively. This might be attributed to the dissolution of $\left(\mathrm{NH}_{4}\right)_{2}$
$\mathrm{NO}_{3}$ from the soil surface and nitrification of $\mathrm{NH}_{4}$ to $\mathrm{NO}_{3}$ at the soil surface especially in the flood irrigation. These results are in agreement with those obtained by Bilal et al. (1979). Also, El fayoumy et al. (2000) who reported that the losses nitrogen via leaching was mainly in the form of $\mathrm{NO}_{3}-\mathrm{N}$ for ammonium nitrate.

\subsection{Changes in soil parameters after pepper harvest}

\subsubsection{Soil salinity}

The values of $\mathrm{pH}$ and $\mathrm{EC}$ are important indicators of the soil status as they affect the chemical and physical processes in the soil. For example, the values of $\mathrm{pH}$ and EC have a direct impact on microbial activity and thus they indirectly affect nitrification and denitrification. These processes are important for the availability of $\mathrm{N}$ in the rhizosphere. This was confirmed by Simek et al. (2002) and Brady and Weil (1996). Figure (1) show the relative change in EC values (the difference between initial and final soil EC as percent) in the soil during pepper cropping two seasons as affected by ammonium sulphate, ammonium nitrate, compost and compost extract application. Soil salinity (EC) of the surface layer $(0-30 \mathrm{~cm})$ in both seasons, changes to be less in T2, T3, T5 and T6 than that in T1 and T4. Application of ammonium sulphate caused the least reduction in soil salinity compared to ammonium nitrate. The average soil salinity in the beginning and end of the season when soil treated by ammonium 
sulphate or ammonium nitrate $(140 \mathrm{~kg}$ $\mathrm{N} / \mathrm{fed}$ ), soil salinity increased by 3.97 and $2.78 \%$ in $\mathrm{T} 1$ and decreased by $(8.15$, $15.84) \%$ in $\mathrm{T} 2,(24.78,31.24) \%$ in $\mathrm{T} 3$,
$(0.78,2.78) \%$ in $\mathrm{T} 4,(23.97,30.49) \%$ in T5 and $(34.01,39.78) \%$ in T6 during pepper cropping in two season, respectively.

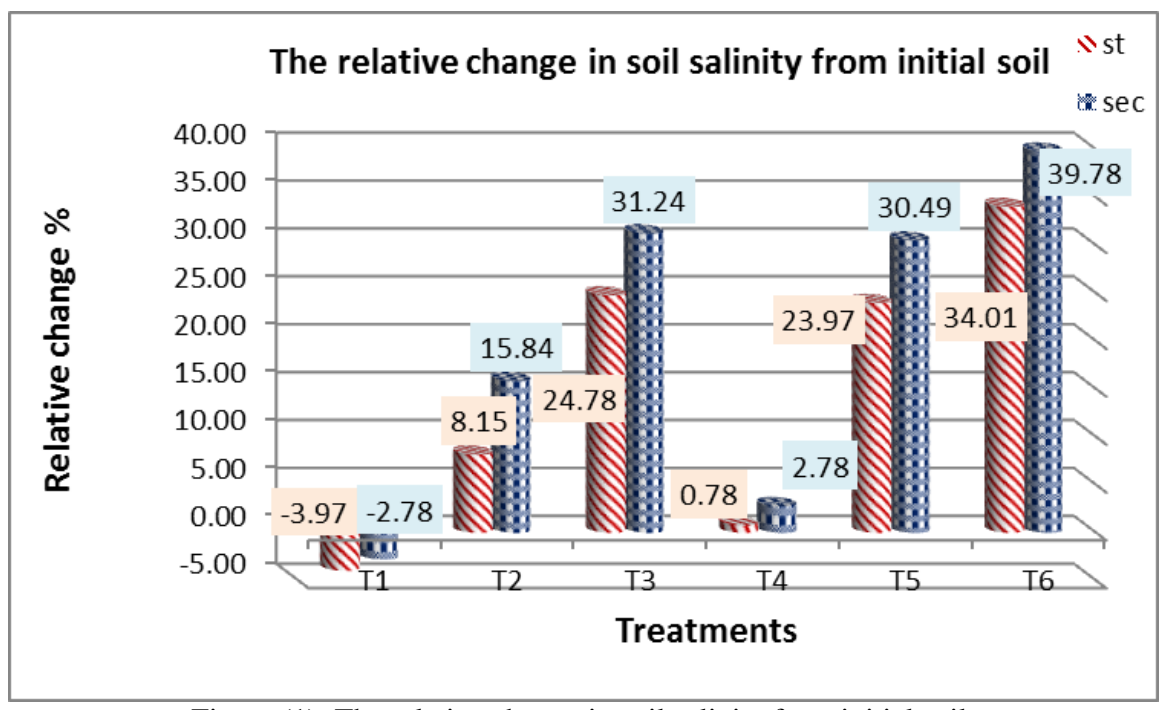

Figure (1): The relative change in soil salinity from initial soil.

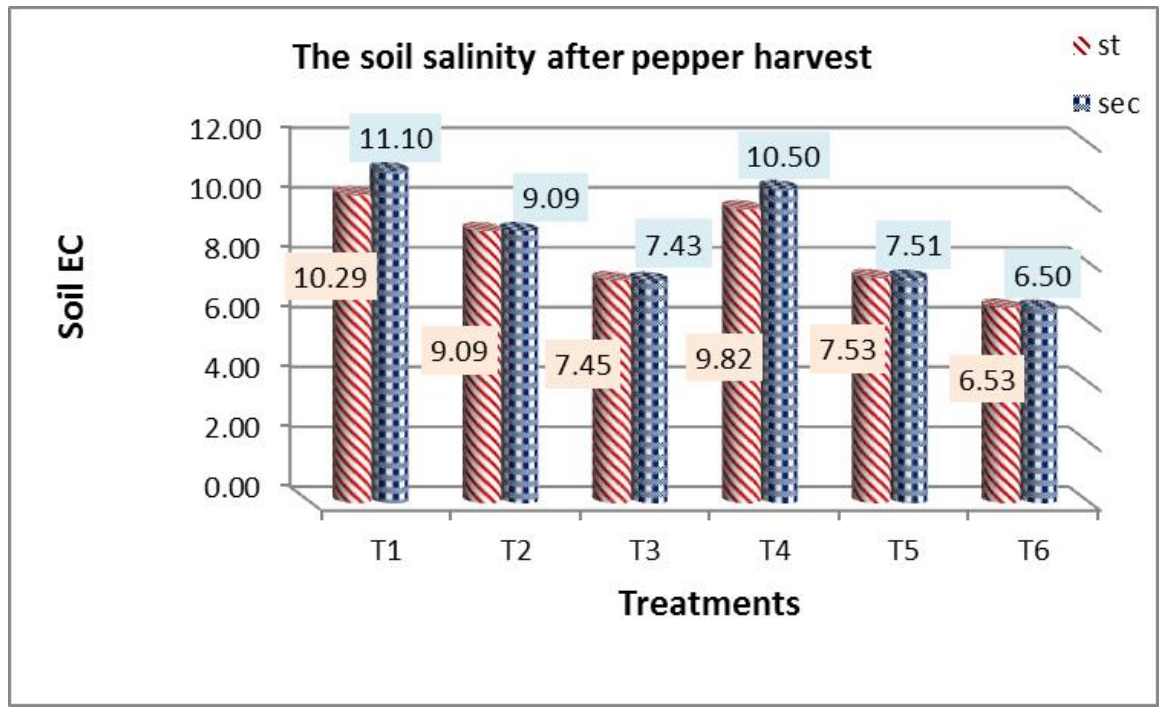

Figure (2): The soil salinity after pepper harvest.

$\mathrm{T} 1$ - Recommended dose of ammonium sulphate, $\mathrm{T} 2-75 \%$ of ammonium sulphate + compost $(2.3$ ton/ fed). T3 $-50 \%$ of ammonium sulphate + Compost (4.6 ton/ fed), T4 - Recommended dose of ammonium nitrate. T5 $-75 \%$ of ammonium nitrate + Compost ( $2.3 \mathrm{ton} / \mathrm{fed}), \mathrm{T} 6-50 \%$ of ammonium nitrate + Compost (4.6ton /fed). 
Reduction in soil salinity is more Pronounce in surface layer inT2, T3, T5 and T6 treatments. Comparison of soil salinity changes for pepper crops confirms that ammonium nitrate has been more effective on soil salinity reduction as compared to ammonium sulphate may be as a result to raising its salt index. This result in harmony with Sina et al. (2012) who reported that application of ammonium nitrate caused the most reduction in soil salinity ( $0-30 \mathrm{~cm}$ depth) compared to urea or ammonium sulphate. Soil salinity changes along the soil profile during the barley cropping season showed that in all soil depths, salinity was reduced. Naceur et al. (2009) reported that application of compost on such affected soil helps to diminish salinity thereby improving soil characteristics mainly by the increase of salts leaching.

\subsubsection{Soil pH and fertility}

Data presented in Table (4) show a nonsignificant change in soil $\mathrm{pH}$ among all treatments. The soil $\mathrm{pH}$ decreased with type and rate of nitrogen fertilizers application. The soil $\mathrm{pH}$ decreased from (7.96 to 7.85$),(8.05$ to 7.82 ) in the first season and from (7.95 to 7.83), (8.03 to 7.81) in the second one for $\left(\mathrm{NH}_{4}\right)_{2} \mathrm{SO}_{4}$ and $\mathrm{NH}_{4} \mathrm{NO}_{3}$ respectively. Using compost during two grown seasons in conjunction with mineral nitrogen fertilizer affect $\mathrm{pH}$ values. This behavior may be due to the organic matter (compost) fraction which have a negative charge surfaces that is raised from the dissociation of $\mathrm{H}^{+}$from certain functional groups particularly from carboxylic ( $\mathrm{COOH})$ and phenolic $\left({ }^{-} \mathrm{C} 6 \mathrm{H} 4 \mathrm{OH}\right)$ groups (Jakub Elbl et al., 2014). Compost was added for saline soils reclamation to improve its physical, chemical and biological properties as well as the crop yield. In general, the application of compost and Compost extract integrated with mineral nitrogen fertilizer could give an economic yield of pepper and raise soil organic matter. Data in Table (4) indicate that the soil organic matter content ranged from ( 0.37 to 0.89$),(0.21$ to 0.8$) \%$ in first season and from $(0.48$ to 1.0$),(0.32$ to 0.91$)$ in the second season for $\left(\mathrm{NH}_{4}\right)_{2} \mathrm{SO}_{4}$ and $\mathrm{NH}_{4} \mathrm{NO}_{3}$ respectively. This is consistent with the results of Tejada et al. (2006) in which the effect of compost on soil organic carbon depended on the chemical nature of the amendments. The role of compost in salt-affected soils is very vital because the organic source is of ultimate opportunity to improve the physical properties of such soils which have been deteriorated to the extent that water and air passage become extremely difficult in such soils. The ground water stands on the surface of these soils for weeks long. The plants when grown under these conditions often die due to deficiency of root respiration. The compost can be a very good organic amendment in saline agriculture as well as for reclamation of salt-affected soils (Zaka et al., 2003).

\subsubsection{Available macronutrients in soil}

The presented data in Table (4) show the available $\mathrm{P}$ and $\mathrm{K}\left(\mathrm{mg} \mathrm{kg}^{-1}\right)$. This content 
increased as a result of using compost in salt affected soil in conjunction with mineral nitrogen fertilizer. This increase may be attributed to the effect of different application rates of compost which caused an increase in the availability of $K$ in the soil. On the other hand, the effect of compost on available $\mathrm{P}$ was non-significant even with high rates of application, but this effect was significant for available $\mathrm{K}$ in the first season. This finding is in agreement with that obtained by Voorhees and Uresk (1990) and Mohammad (2010). In general, the application of compost increased the solubility of all tested nutrients in the studied soil. These results are in agreement with El-rashidi et al. (2010) who found that the application of peat improved the solubility of most nutrients in the soil.

\subsubsection{Available micronutrients in soil}

It is evident from data presented in Table (4) that pronounced increases available microelement ( $\mathrm{Fe}, \mathrm{Mn}$ and $\mathrm{Zn})$ were as a result of high rate of compost application. The more pronounced increase in the available $\mathrm{Fe}, \mathrm{Mn}$ and $\mathrm{Zn}$ as a result of increasing the applied rates of compost may be attributed to its role in improving soil $\mathrm{pH}$. This finding is in agreement with results obtained by Mohammad (2010). He and Li (2004) indicated that the application of organic combined with inorganic fertilizers led to increase the activities of available nutrient content in soil. This is due salinity.to decreasing both soil $\mathrm{pH}$ and soil.

Table (4): Soil pH, EC, O.M. and its content of available macro and micro nutrients in the studied soil after plant harvesting.

\begin{tabular}{|c|c|c|c|c|c|c|c|c|}
\hline \multirow[t]{2}{*}{ Treatments } & \multirow[t]{2}{*}{ Rate } & \multirow{2}{*}{$\begin{array}{c}\mathrm{pH} \\
(1: 2.5)\end{array}$} & \multirow[t]{2}{*}{ O.M \% } & \multicolumn{2}{|c|}{$\begin{array}{l}\text { Macronutrients } \\
\left(\mathrm{mgkg}^{-1}\right)\end{array}$} & \multicolumn{3}{|c|}{$\begin{array}{c}\text { Micronutrients } \\
\left(\mathrm{mgkg}^{-1}\right)\end{array}$} \\
\hline & & & & $\mathrm{P}$ & $\mathrm{K}$ & $\mathrm{Fe}$ & $\mathrm{Mn}$ & $\mathrm{Zn}$ \\
\hline \multicolumn{9}{|c|}{ First Season } \\
\hline \multirow{3}{*}{$\left(\mathrm{NH}_{4}\right)_{2} \mathrm{SO}_{4}$} & $100 \%$ mineral & 7.96 & 0.37 & 1.1 & 36 & 28 & 6 & 33 \\
\hline & $75 \% \min +2.3$ & 7.86 & 0.85 & 1.3 & 37 & 30 & 6 & 44 \\
\hline & $50 \% \min +4.6$ & 7.85 & 0.89 & 2.2 & 39 & 33 & 9 & 51 \\
\hline \multirow{3}{*}{$\mathrm{NH}_{4} \mathrm{NO}_{3}$} & $100 \%$ mineral & 8.05 & 0.21 & 1.0 & 35 & 27 & 7 & 30 \\
\hline & $75 \% \min +2.3$ & 7.89 & 0.60 & 1.5 & 39 & 30 & 8 & 31 \\
\hline & $50 \% \min +4.6$ & 7.82 & 0.80 & 1.9 & 39 & 34 & 9 & 31 \\
\hline Mean & & 7.91 & 0.62 & 1.3 & 1.3 & 30 & 7 & 37 \\
\hline LSD 5\% & & 0.082 & 0.322 & 0.07 & 0.07 & 0.01 & 0.04 & 0.08 \\
\hline \multicolumn{9}{|c|}{ Second Season } \\
\hline \multirow{3}{*}{$\left(\mathrm{NH}_{4}\right)_{2} \mathrm{SO}_{4}$} & $100 \%$ mineral & 7.95 & 0.48 & 2.1 & 47 & 42 & 15 & 61 \\
\hline & $75 \% \min +2.3$ & 7.85 & 0.96 & 2.3 & 45 & 40 & 19 & 54 \\
\hline & $50 \% \min +4.6$ & 7.83 & 1.00 & 3.1 & 49 & 37 & 15 & 43 \\
\hline \multirow{3}{*}{$\mathrm{NH}_{4} \mathrm{NO}_{3}$} & $100 \%$ mineral & 8.03 & 0.32 & 1.8 & 45 & 44 & 17 & 41 \\
\hline & $75 \% \min +2.3$ & 7.88 & 0.71 & 1.9 & 0.49 & 39 & 18 & 40 \\
\hline & $50 \% \min +4.6$ & 7.81 & 0.91 & 2.5 & 48 & 37 & 18 & 40 \\
\hline Mean & & 7.886 & 0.732 & 2.29 & 2.29 & 39.9 & 170 & 46.7 \\
\hline LSD 5\% & & 0.3216 & 0.0838 & 0.043 & 0.043 & 0.58 & 4.24 & 0.58 \\
\hline
\end{tabular}




\subsection{Leaching of mineral nitrogen during soil layers}

Compost can be used not only to increase soil fertility but also to reduce the leaching of mineral nitrogen. Leaching of mineral nitrogen from arable soil is a major threat to the drinking water quality of underground reservoirs.

\subsection{1 $\mathrm{NO}_{3}-\mathrm{N}$}

The concentration of $\mathrm{NO}_{3}-\mathrm{N}$ in different soil layers during two seasons is illustrated in Figure (3a, b and c). Results showed generally that $\mathrm{NO}_{3}-\mathrm{N}$ concentration in surface and subsurface layers were higher in first season compared the second one. On the other hand, $\mathrm{NO}_{3}-\mathrm{N}$ concentrations in deep layers were higher in first season and the highest value exists in treatment (T1 and T4). This behavior may be due to the higher rate of mineral nitrogen fertilization and the water table levels close to surface, which caused quick nitrate losses in water table and transformation (nitrification) of $\mathrm{NH}_{4}-\mathrm{N}$ to $\mathrm{NO}_{3}-\mathrm{N}$. This means that the concentration of nitrate- $\mathrm{N}$ increased with soil depth and successive addition of fertilizer. El-Fayoumy et al. (2000) reported that nitrate losses in water table and soil, increased the number of years of cover cropping under successive uses of nitrogen fertilizer. The concentration of $\mathrm{NO}_{3}-\mathrm{N}$ in surface layer ranged from 8.79-18.7 and 8.93-18.98 ppm in $1^{\text {st }}$ and $2^{\text {nd }}$ season for $\mathrm{T} 1$ and $\mathrm{T} 4$, respectively. While the corresponding values in subsurface layer $(30-60 \mathrm{~cm})$ were 20.88 42.07 and 17.76-42.73 ppm and in deep layer $(60-90 \mathrm{~cm})$ were $52.62-94.89$ and $33.76-67.78$ in first and second season, respectively. While in case of $\mathrm{T} 2, \mathrm{~T} 3, \mathrm{~T} 5$ and $\mathrm{T} 6$, the $\mathrm{NO}_{3}-\mathrm{N}$ concentration were lower than that in $\mathrm{T} 1$ and $\mathrm{T} 4$ treatments in all soil layers as a result of rationalization of mineral nitrogen fertilizer by using compost for managing soil nitrogen to prevent nitrate- $\mathrm{N}$ leaching in intensive agriculture system.

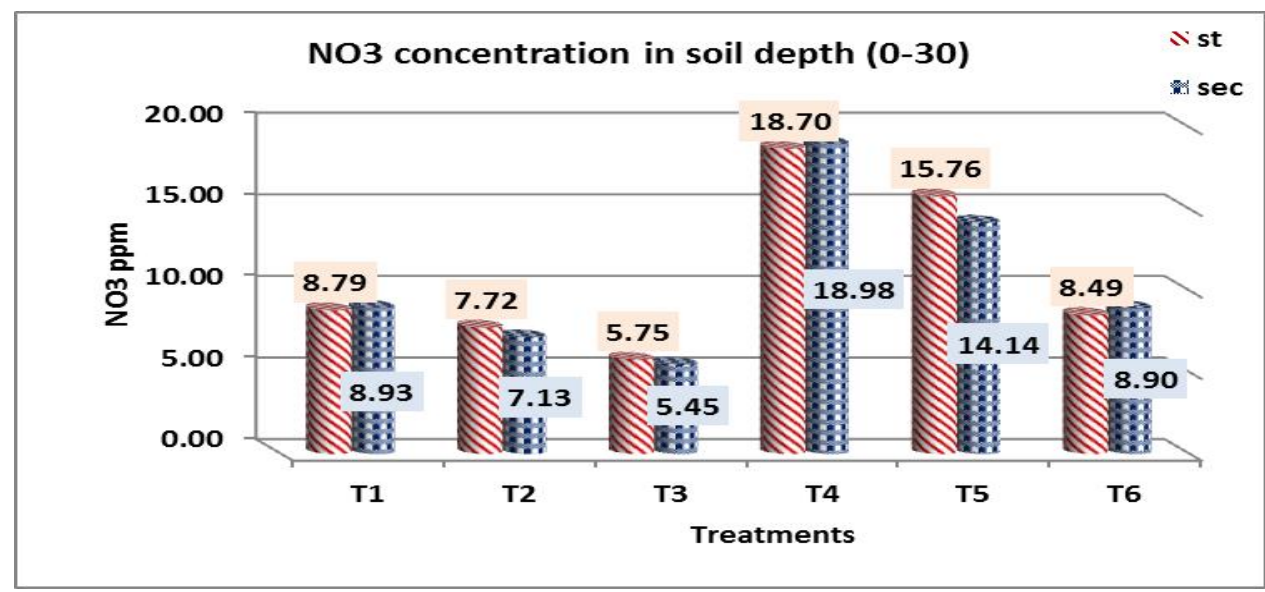

Figure (3-a): $\mathrm{NO}_{3}$ concentration in soil depth (0-30). 


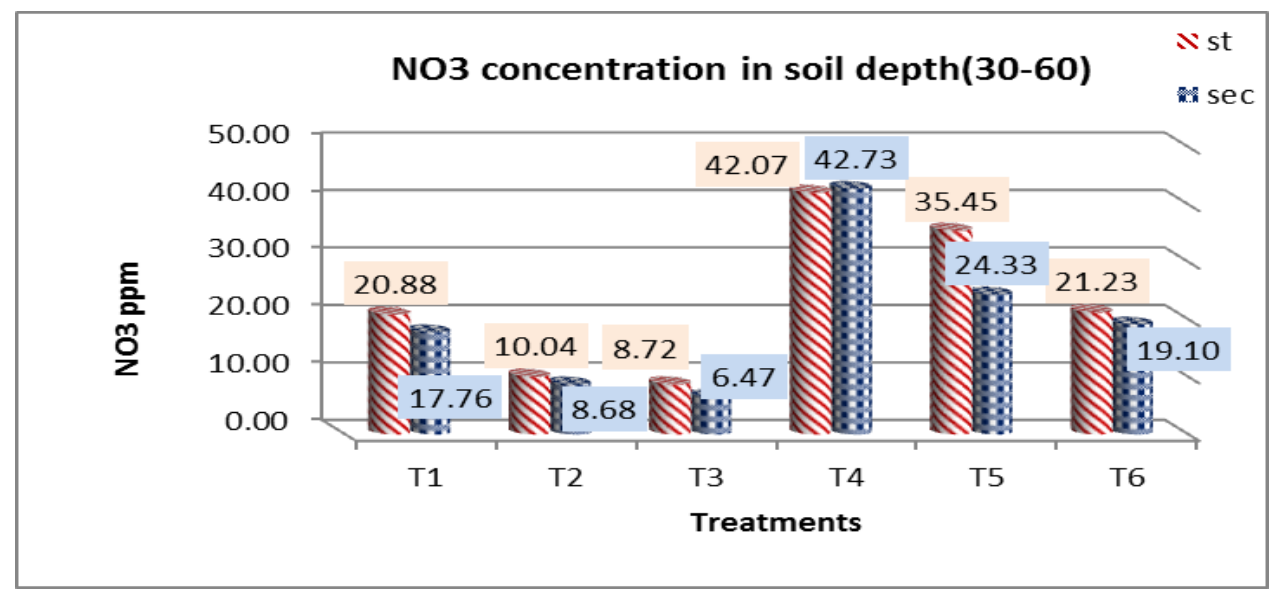

Figure (3-b): $\mathrm{NO}_{3}$ concentration in soil depth (30-60).

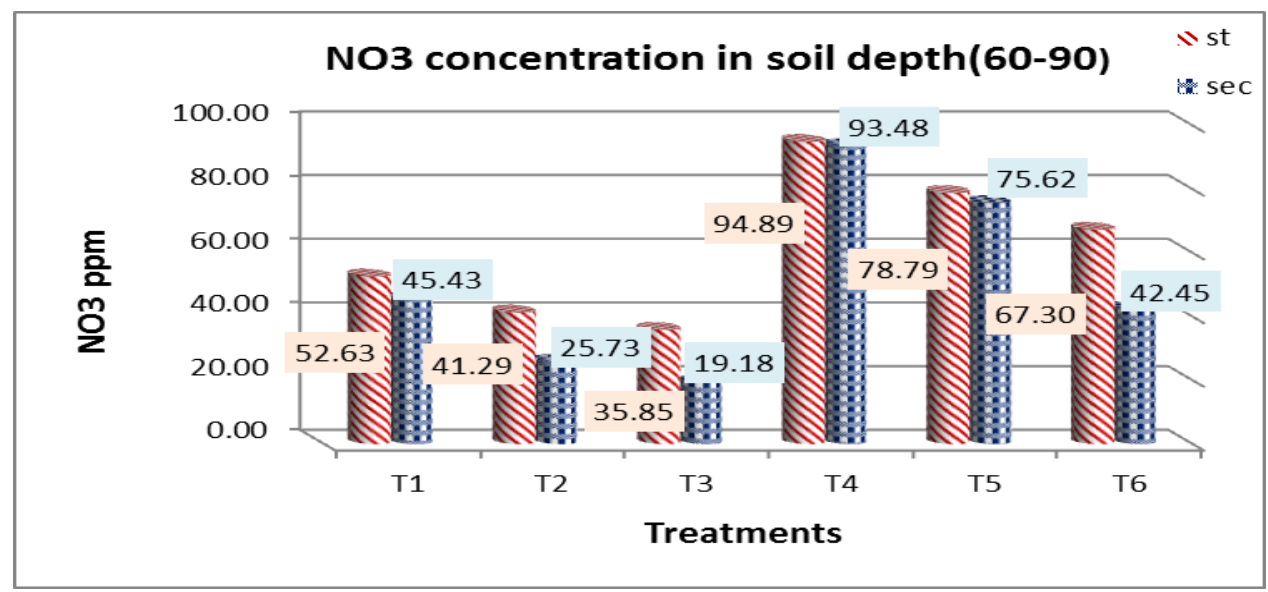

Figure (3-c): $\mathrm{NO}_{3}$ concentration in soil depth (60-90).

T1 - Recommended dose of ammonium sulphate, T2 - 75\% of ammonium sulphate + compost (2.3 ton/ fed). T3 $-50 \%$ of ammonium sulphate + compost ( 4.6 ton/ fed), T4 - Recommended dose of ammonium nitrate. T5 - 75\% of ammonium nitrate + Compost ( 2.3 ton/ fed $),$ T6 - 50\% of ammonium nitrate + Compost (4.6ton /fed).

\subsection{2 $\mathrm{NH}_{4}-\mathrm{N}$}

The concentration of NH4-N in different soil layers at two cropping seasons illustrated in Figure (4a, b and c). The data indicates that $\mathrm{NH}_{4}-\mathrm{N}$ concentration in surface layer followed the descending order of $\mathrm{T} 1>\mathrm{T} 4>\mathrm{T} 2>\mathrm{T} 5>\mathrm{T} 3>\mathrm{T} 6$ in $1^{\text {st }}$ and $2^{\text {nd }}$ season. Almost the same trend was recorded in subsurface layers in both seasons. On the other hand, $\mathrm{NH}_{4}-\mathrm{N}$ concentrations in deep layers were higher in first season than that in the second one since the highest value existed in 
treatment T1and T4 in $1^{\text {st }}$ and $2^{\text {nd }}$ season. Again, this might be due to intensive nitrogen fertilization and shallow water table level. These results are in agreement with those obtained by ElFayoumy et al. (2000). Finally, the positive effect of compost addition on leaching of $\mathrm{N}$-min is based on its chemical composition; available carbon is a source of energy for microorganisms, thus this energy can be subsequently used for the processing of nitrogen. Increasing microbial activity results in increased capacity for mineral nitrogen retention (additionally supplied from compost and another mineral fertilizer). Mineral nitrogen is captured in soil organic matter (Diaz et al., 2007; Galloway and Cowling, 2002). These findings again suggest major annual economic losses to producers and the potential risk of environmental damage from excess application of $\mathrm{N}$, but also suggest the importance of integrated use of Compost with chemical NPK fertilizers in minimizing the accumulation of residual $\mathrm{NO}_{3}-\mathrm{N}$ in soil after harvest, and its subsequent leaching.

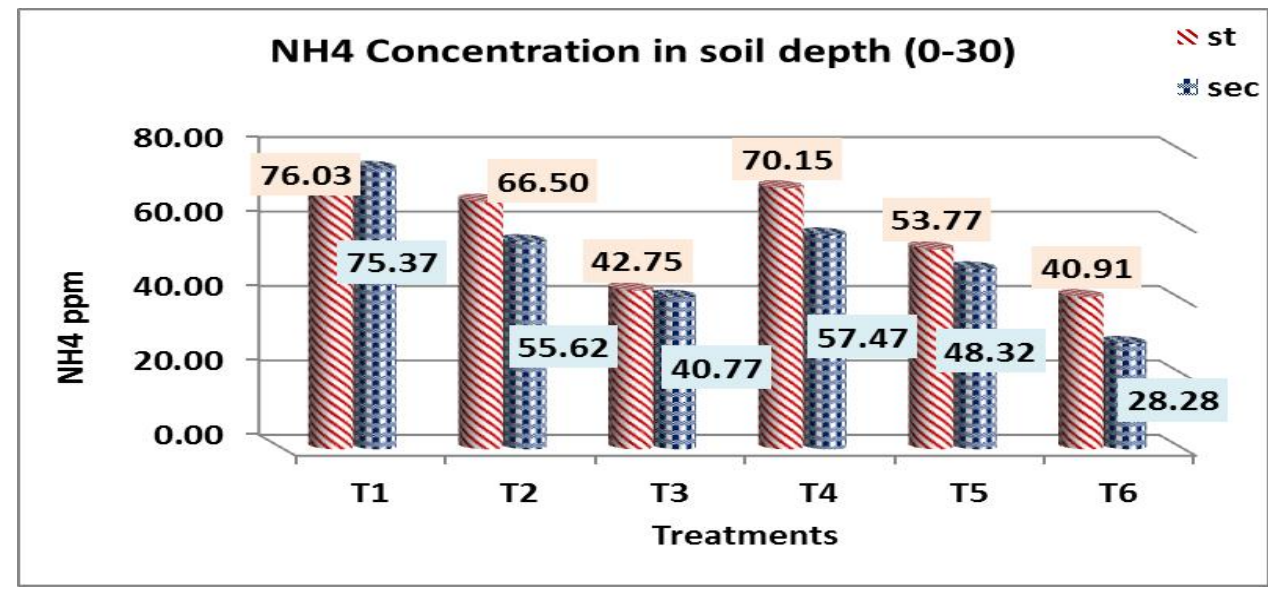

Figure (4-a): $\mathrm{NH}_{4}$ concentration in soil depth (0-30).

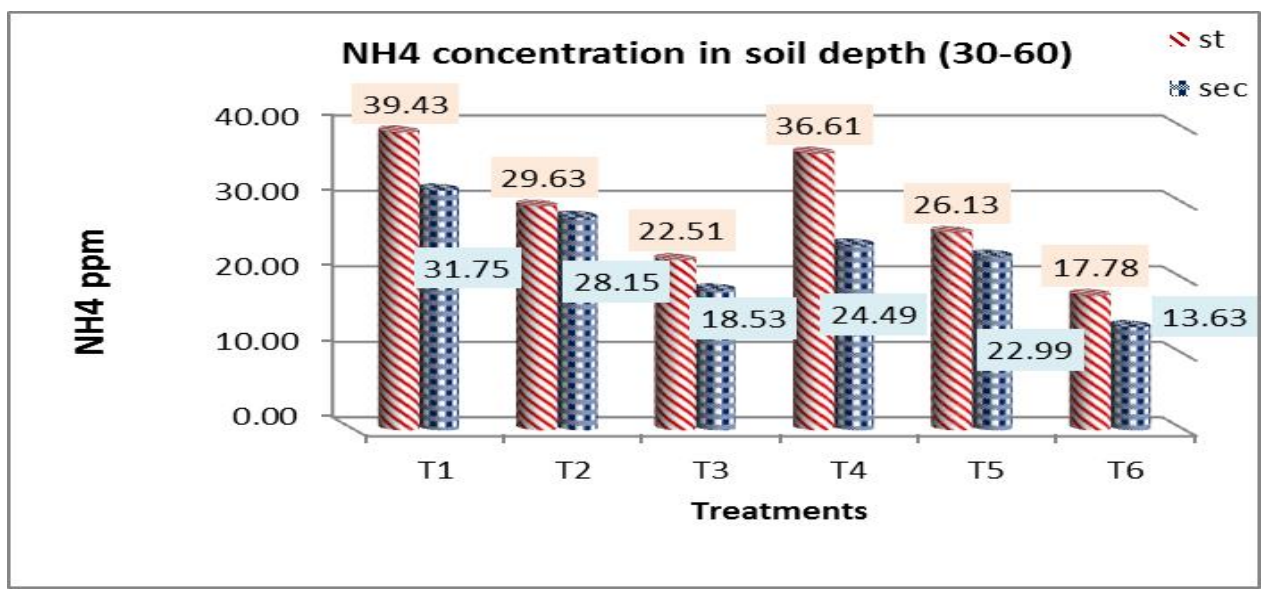

Figure (4-b): $\mathrm{NH}_{4}$ concentration in soil depth (30-60). 


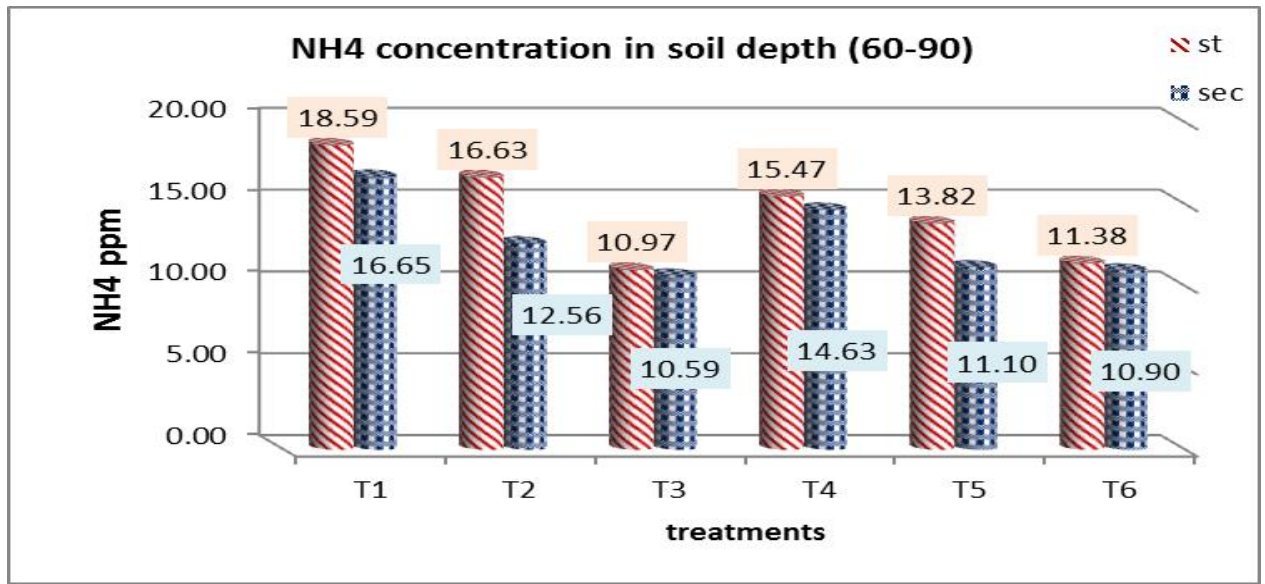

Figure (4-c): $\mathrm{NH}_{4}$ concentration in soil depth (60-90).

T1 - Recommended dose of ammonium sulphate, T2 $-75 \%$ of ammonium sulphate + compost $(2.3$ ton/ fed). T3 - 50\% of ammonium sulphate + compost (4.6 ton/ fed), T4 - Recommended dose of ammonium nitrate. T5 $-75 \%$ of ammonium nitrate + compost (2 .3ton/ fed), T6 - 50\% of ammonium nitrate + compost (4.6 ton /fed).

3.4 Yield and yield components as affected by different source of nitrogen fertilizers

Figure (5a, b, c and d) show the effect of using compost integrated with mineral nitrogen fertilizer on yield parameters of pepper plants. It is clear that significant differences in various yield characters were noted. It also shows that maximum number of fruits per plant (22.43) were recorded in T1 and T4 (that received 140 $\mathrm{kgN} / \mathrm{fed}$ ) followed by $\mathrm{T} 2$ and $\mathrm{T} 5$ (that received 2.3 tons compost $+105 \mathrm{~kg}$ $\mathrm{N} / \mathrm{fed}$ ), while minimum number of fruits per plant were recorded in $\mathrm{T} 3$ and $\mathrm{T} 6$ (that received 4.6 tons compost $+70 \mathrm{~kg}$ $\mathrm{N} / \mathrm{fed}$ ). Increase in number of fruits per plant is due to the production of more number of flowers, higher percentage of fruit set and reduced shedding of flowers and fruits. Similar results were obtained by Tripathy and Maity (2011). These results are in good agreement with those obtained by Suge et al. (2011) who stated that increasing NPK from 50\% to $100 \%$ of the recommended rates encouraged the vegetative growth of eggplants as expressed as plant height and fresh weight besides increasing the total yield and enhanced the fruit quality. It could be noticed that the compost improves soil physical and chemical properties such as aggregation, soil aeration and lower bulk density which led to easy leaching of soluble salts from the soil and increase its productivity. 
Hafez. Wafaa / Archives of Agricultural Sciences Journal 1(1) 96-120, 2018.

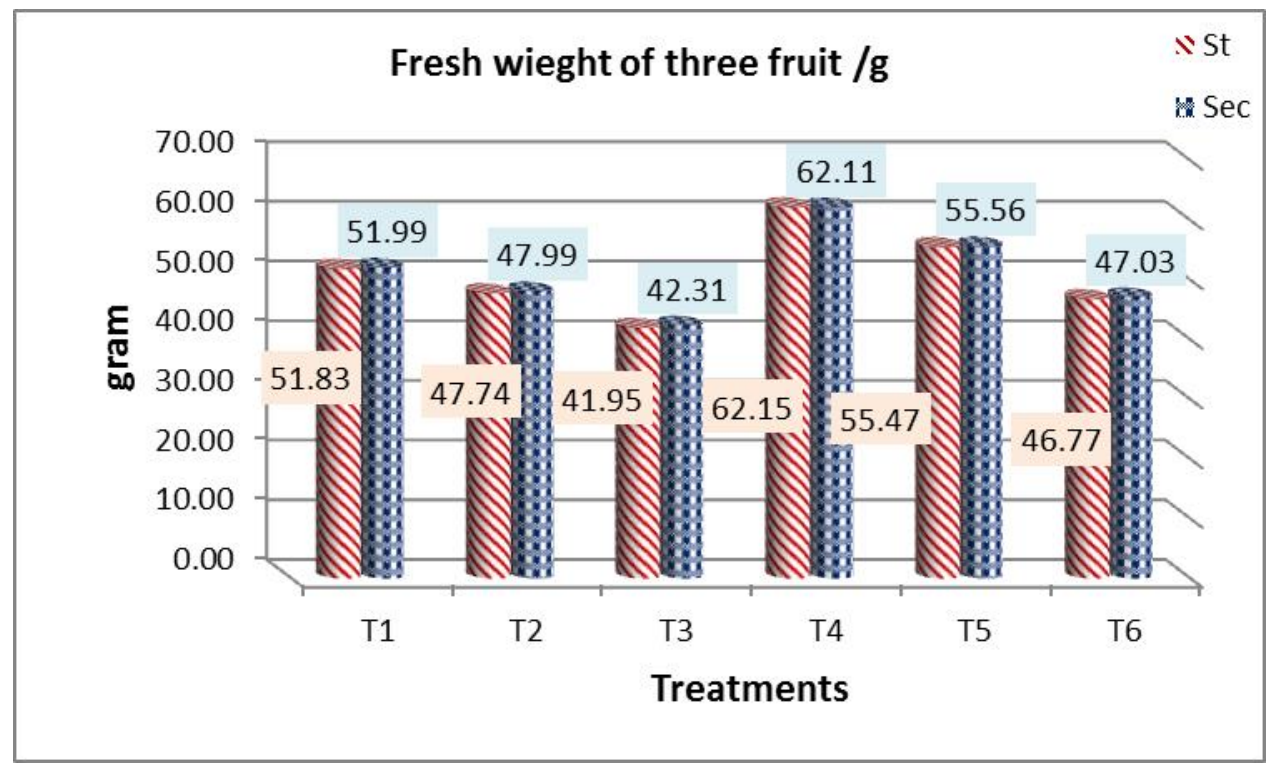

Figure (5-a): Fruit fresh weight g/plant.

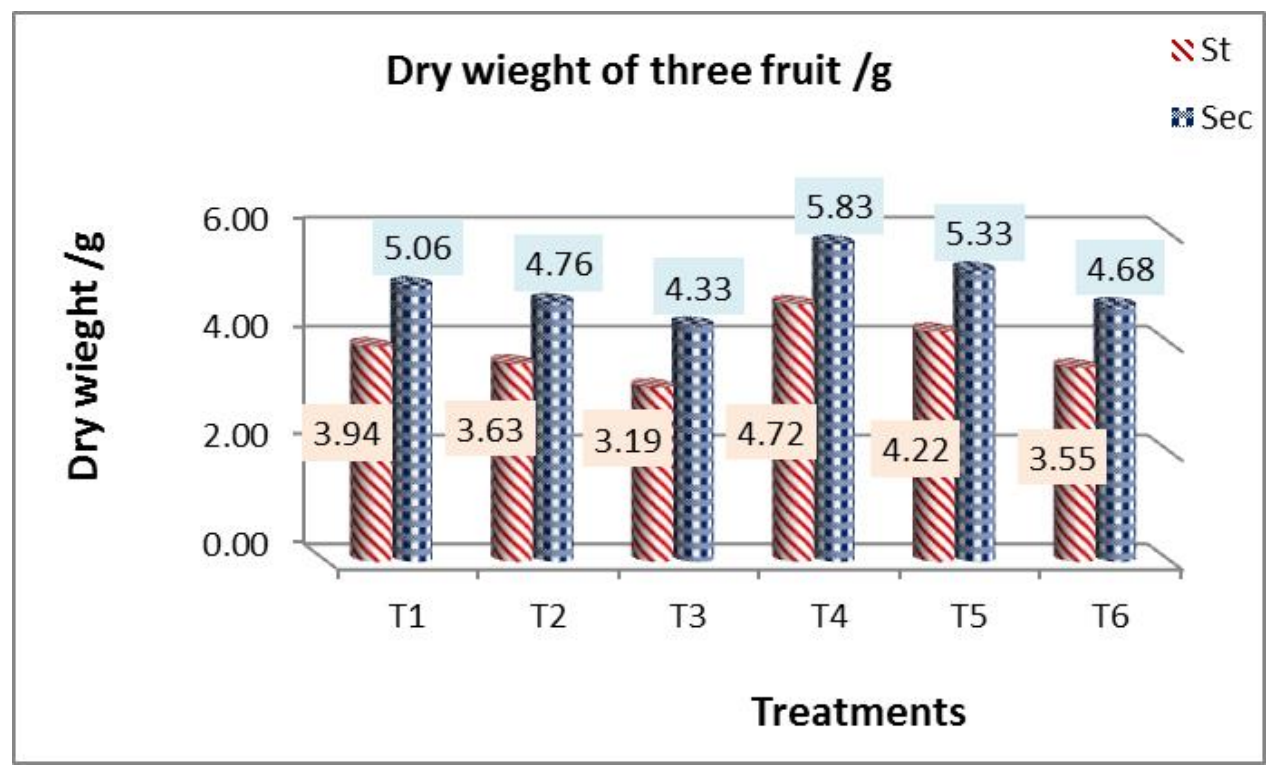

Figure (5-b): Fruit dry weight g/plant. 


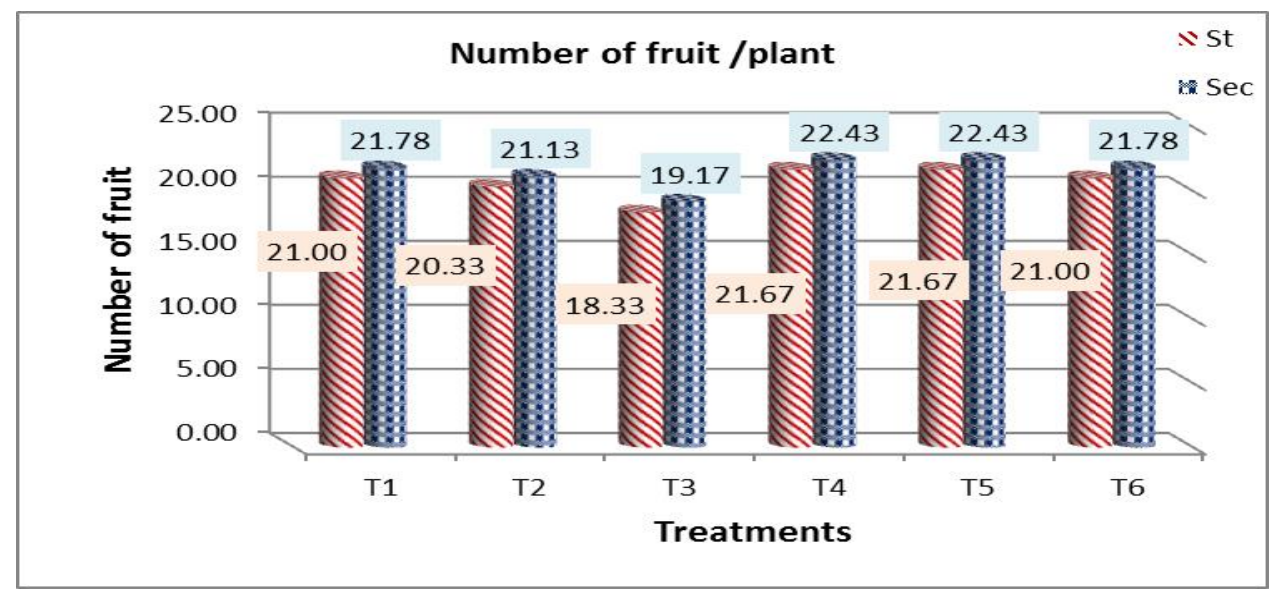

Figure (5-c): Fruit No./plant.

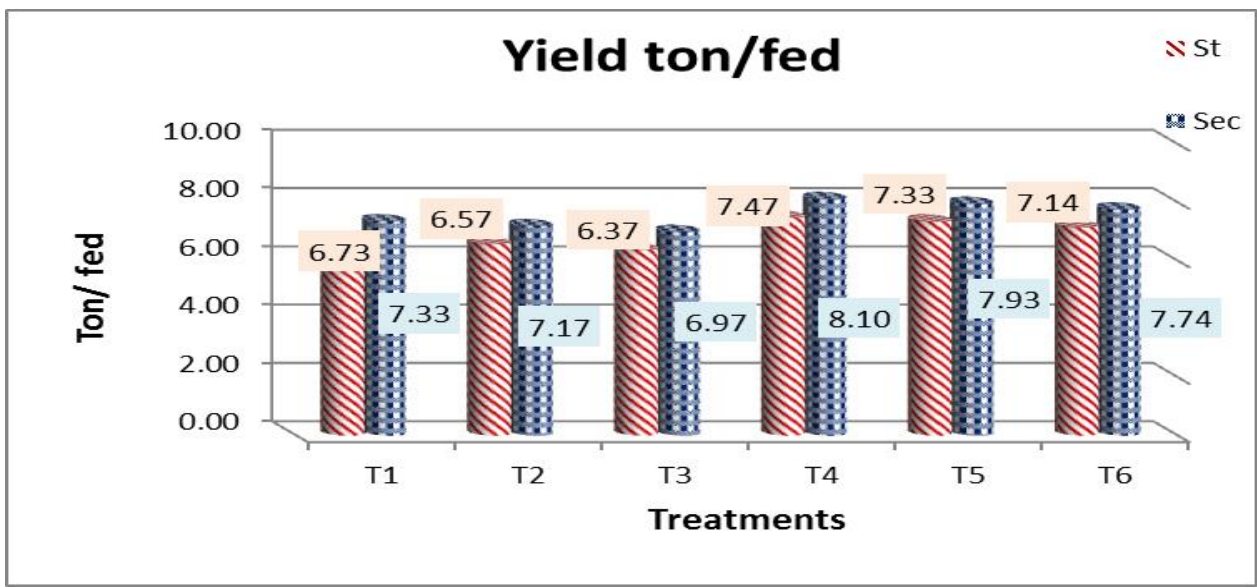

Figure (5-d): Fruit yield/plant.

T1 - Recommended dose of ammonium sulphate, T2 - 75\% of ammonium sulphate + compost (2.3 ton/ fed). T3 - 50\% of ammonium sulphate + Compost (4.6 ton/ fed), T4 - Recommended dose of ammonium nitrate. T5 $-75 \%$ of ammonium nitrate + compost $(2.3$ ton/ fed $)$, T6 - $50 \%$ of ammonium nitrate + compost (4.6ton /fed).

3.5 Nitrate $\left(\mathrm{NO}_{3^{-}}\right)$and Nitrite $\left(\mathrm{NO}_{2^{-}}\right)$ concentrations in the pepper fruit

Data in Table (5) shows the concentrations of nitrate and nitrite in pepper fruit, data revealed that .concentration of nitrate varied from
201.78 to 40.21 and from 175.55 to 45.5 $\mu \mathrm{gg}^{-1}$ in $1^{\text {st }}$ and $2^{\text {nd }}$ season, respectively. Results indicate that $\mathrm{NO}_{3}-\mathrm{N}$ concentration in pepper fruit could arrange in descending orders follows: $\mathrm{T} 4>\mathrm{T} 1>\mathrm{T} 2>\mathrm{T} 5>\mathrm{T} 6>$ and $\mathrm{T} 3$ in both seasons. While, the average of nitrite concentrations recorded for the $100 \%$ 
mineral $\mathrm{N}$ treatment for $\left(\mathrm{NH}_{4}\right)_{2} \mathrm{SO}_{4}$ and $\mathrm{NH}_{4} \mathrm{NO}_{3}$ fertilizers are 60.22 and 159.55 $\mu \mathrm{gg}^{-1}$ in $1^{\text {st }}$ and $69.4,113.72$ in $2^{\text {nd }}$ season for (T1 and T4). The $\mathrm{NO}_{2}-\mathrm{N}$ concentration in pepper fruit could arrange in descending orders as follows:
T4> T5> T1 > T6> T2> and T3 in both seasons. These were also in agreement with the fact that nitrite contents in vegetables are usually very low compared to nitrate (Aworh et al., 1980; Hunt and Turner, 1994).

Table (5): Concentrations of nitrate $\left(\mathrm{NO}_{3}{ }^{-}\right)$and nitrite $\left(\mathrm{NO}_{2}{ }^{-}\right)$in pepper fruit.

\begin{tabular}{|c|c|c|c|}
\hline Treatments & Rate & Nitrate $\left(\mathrm{NO}_{3}^{-}\right) \mu \mathrm{gg}-1$ & Nitrite $\left(\mathrm{NO}_{2}^{-}\right) \mu g g-1$ \\
\hline \multicolumn{4}{|c|}{ First season } \\
\hline \multirow{3}{*}{$\left(\mathrm{NH}_{4}\right)_{2} \mathrm{SO}_{4}$} & $100 \%$ mineral & 108.31 & 60.22 \\
\hline & $75 \% \min +2.3$ ton compost & 60.0 & 30.11 \\
\hline & $50 \% \min +4.6$ ton compost & 40.21 & 20.8 \\
\hline \multirow{3}{*}{$\mathrm{NH}_{4} \mathrm{NO}_{3}$} & $100 \%$ mineral & 201.78 & 159.55 \\
\hline & $75 \% \min +2.3$ ton compost & 144.25 & 70.8 \\
\hline & $50 \% \min +4.6$ ton compost & 80.23 & 30.46 \\
\hline LSD 5\% & & 2.76 & 6.45 \\
\hline \multicolumn{4}{|c|}{ Second season } \\
\hline \multirow{3}{*}{$\left(\mathrm{NH}_{4}\right)_{2} \mathrm{SO}_{4}$} & $100 \%$ mineral & 113.72 & 69.4 \\
\hline & $75 \% \min +2.3$ ton compost & 62.5 & 36.11 \\
\hline & $50 \% \min +4.6$ ton compost & 45.5 & 27.63 \\
\hline \multirow{3}{*}{$\mathrm{NH}_{4} \mathrm{NO}_{3}$} & $100 \%$ mineral & 175.55 & 143.39 \\
\hline & $75 \% \min +2.3$ ton compost & 135.12 & 71.51 \\
\hline & $50 \% \min +4.6$ ton compost & 76.36 & 32.64 \\
\hline LSD 5\% & & 2.40 & 2.29 \\
\hline
\end{tabular}

\subsection{Nitrate ( $\left.\mathrm{NO}^{-}\right)$and Nitrite ( $\left.\mathrm{NO}^{-}\right)$} concentrations in the soil samples after harvesting

Table 6 presents the concentration levels of nitrate and nitrite in the soil samples. Nitrate levels are slightly higher than nitrite in case of the two mineral nitrogen fertilizers used. Nitrate levels in T4 recorded the highest residual value of 411.3 and $417.5 \mu \mathrm{gg}^{-1}$ in first and second season, respectively. The average nitrite concentrations recorded for the $100 \%$ mineral $\mathrm{N}$ treatment for $\mathrm{NH}_{4} \mathrm{NO}_{3}$ and
$\left(\mathrm{NH}_{4}\right)_{2} \mathrm{SO}_{4}$ fertilizers are 843.6 and $801.42 \mu \mathrm{gg}^{-1}$ in $1^{\text {st }}$ and $2^{\text {nd }}$ season. The statistical test revealed significant differences $(p<0.05)$ between the soil's nitrate and nitrite concentrations in soil samples treated with $100 \%$ mineral nitrogen fertilizer and either 25 or $50 \%$ of integrated compost treatments. This might also be attributed to possible pollution of the soils as a result of excessive usage of fertilizers, herbicides and other agro-chemicals, and as well as the use of waste water in irrigation, and the environmental conditions pertinent in the areas. 
Hafez. Wafaa / Archives of Agricultural Sciences Journal 1(1) 96-120, 2018.

Table (6): Concentrations of nitrate $\left(\mathrm{NO}_{3^{-}}\right)$and nitrite $\left(\mathrm{NO}_{2^{-}}\right)$in the soil samples after harvesting.

\begin{tabular}{|c|c|c|c|}
\hline Treatments & Rate & Nitrate $\left(\mathrm{NO}_{3^{-}}\right) \mu g g-1$ & Nitrite $\left(\mathrm{NO}_{2}{ }^{-}\right) \mu g g-1$ \\
\hline \multicolumn{4}{|c|}{ First Season } \\
\hline \multirow{3}{*}{$\left(\mathrm{NH}_{4}\right)_{2} \mathrm{SO}_{4}$} & $100 \%$ mineral & 347.35 & 478.91 \\
\hline & $75 \% \min +2.3$ ton compost & 196.83 & 243.18 \\
\hline & $50 \% \min +4.6$ ton compost & 136.97 & 194.33 \\
\hline \multirow{3}{*}{$\mathrm{NH}_{4} \mathrm{NO}_{3}$} & $100 \%$ mineral & 411.30 & 843.60 \\
\hline & $75 \% \min +2.3$ ton compost & 346.67 & 395.64 \\
\hline & $50 \% \min +4.6$ ton compost & 196.76 & 177.93 \\
\hline LSD 5\% & & 6.004 & 43.23 \\
\hline \multicolumn{4}{|c|}{ Second season } \\
\hline \multirow{3}{*}{$\left(\mathrm{NH}_{4}\right)_{2} \mathrm{SO}_{4}$} & $100 \%$ mineral & 299.90 & 474.96 \\
\hline & $75 \% \min +2.3$ ton compost & 172.55 & 261.02 \\
\hline & $50 \% \min +4.6$ ton compost & 128.62 & 212.13 \\
\hline \multirow{3}{*}{$\mathrm{NH}_{4} \mathrm{NO}_{3}$} & $100 \%$ mineral & 417.53 & 801.42 \\
\hline & $75 \% \min +2.3$ ton compost & 332.72 & 410.85 \\
\hline & $50 \% \min +4.6$ ton compost & 186.10 & 197.88 \\
\hline LSD 5\% & & 47.75 & 41.07 \\
\hline
\end{tabular}

\subsection{Transfer factors (TF) for nitrate and nitrite from soils to pepper fruit}

Figure $(6 a$ and $6 b)$ presents the transfer factors of nitrate and nitrite from soils to the pepper fruit. Transfer factors for the anions between the soils and vegetables identify the efficiency of a vegetable species to accumulate nitrate and nitrite. Transfer factors were computed to quantify the relative differences in bioavailability of anions to plants or to identify the efficiency of a plant species to accumulate a given anion. These factors were based on the root uptake of the anions (Lokeshwari and Chandrappa, 2006). These results revealed that the nitrate accumulation had a close relationship with the amount of fertilizer applied. The edible parts of the pepper (fruit) grown in $\mathrm{T} 1$ and $\mathrm{T} 4$ accumulated $\left(0.49\right.$ and $\left.0.31 \mathrm{mg} \cdot \mathrm{kg}^{-1}\right)$ and $(0.42$ and $\left.0.38 \mathrm{mg} \mathrm{kg}^{-1}\right)$ of nitrate in $1^{\text {st }}$ and $2^{\text {nd }}$ season. While, $\left(0.29\right.$ and $\left.0.41 \mathrm{mg} \cdot \mathrm{kg}^{-1}\right)$ and $\left(0.35\right.$ and $\left.0.41 \mathrm{mg} \mathrm{kg}^{-1}\right)$ in T3 and T6 in $1^{\text {st }}$ and $2^{\text {nd }}$ season. Also, it was noticed that more nitrate in the edible parts of the plants treated with $140 \mathrm{~kg} / \mathrm{fed}$ mineral fertilizer. The release of nitrogen in organic fertilizers is slower than that in inorganic fertilizers since organic fertilization typically does not provide nitrogen in a readily accessible form. While, the nitrite accumulation in pepper fruit take the same trend with increasing rate of mineral nitrogen fertilizer $(100 \%$ mineral fertilizer) T1 and $\mathrm{T} 4$ for ammonium sulphate and ammonium nitrate. It worth mention, Data observed that TF was recorded a higher values by using ammonium nitrate fertilizer than using ammonium sulphate fertilizer under the levels from two fertilizer types. 


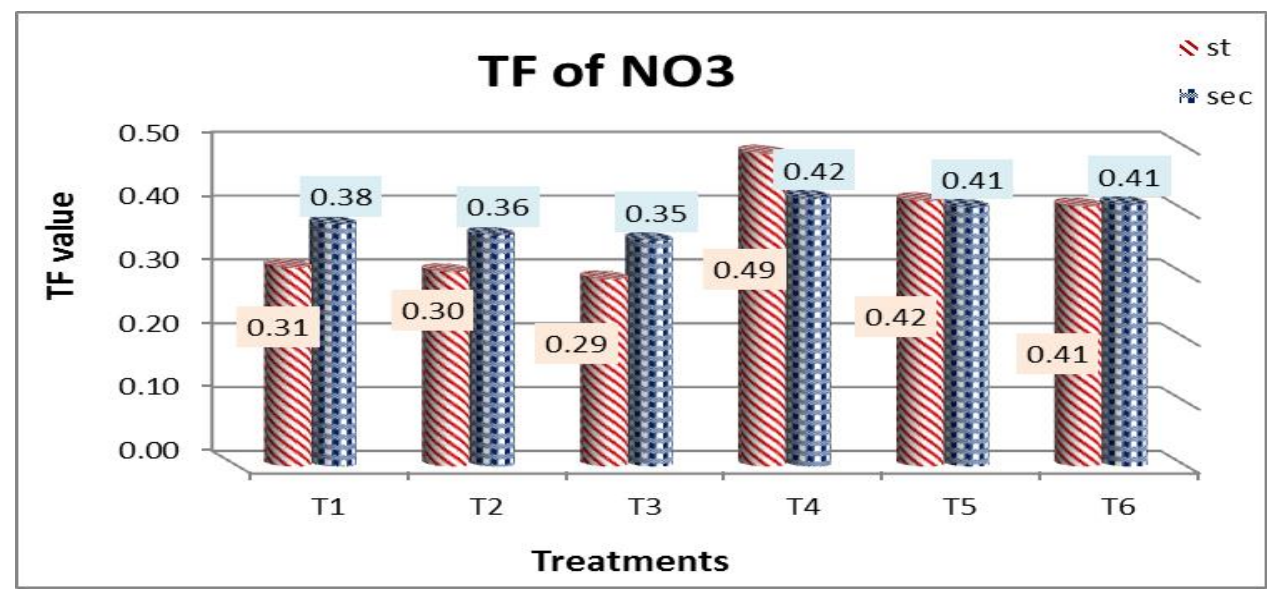

Figure (6-a): TF of nitrate from soil to pepper fruit.

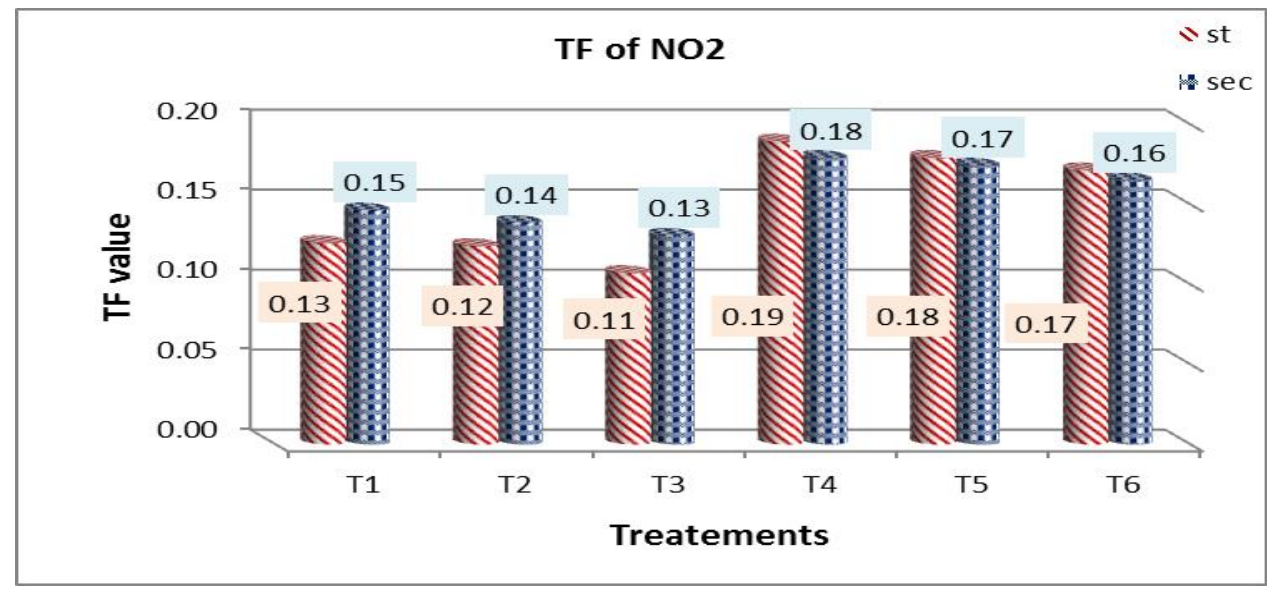

Figure (6-b): TF of nitrite from soil to pepper fruit.

T1 - Recommended dose of ammonium sulphate, T2 - 75\% of ammonium sulphate + compost (2.3 ton/ fed). T3 $-50 \%$ of ammonium sulphate + Compost (4.6ton/ fed), T4 - Recommended dose of ammonium nitrate. T5 - 75\% of ammonium nitrate + compost (2 3 ton/ fed), T6 - 50\% of ammonium nitrate + compost (4.6 ton /fed).

\section{Conclusions}

Mineral fertilizers are the major nutrient input source to improve crop productivity. In the meantime the use of inorganic fertilizers alone may cause problems for human health and the environment and so the need to integrate the organic and inorganic fertilizers is necessary to achieve better crop yields and quality as well as improving physical, biological and chemical properties of the soil. it can 
be recommended that application of the (70 kg N/fed Ammonium sulphate +4 tons/fed compost) produce an economical crop and fertile soil suitable for producing pepper under the conditions of newly reclaimed saline soil and avoid accumulation of nitrate, nitrite and ammonia in fruits and overcome soil and water pollution problems and avoid the bad environmental effect of extra use of nitrogen mineral fertilizers which gave the optimum values of all tested characters.

\section{References}

Abdelbasset, L., Mokded, R., Tahar, G., Francesco, M., Naceur, J. and Chedly, A. (2009), "Effectiveness of compost use in salt-affected soil", Journal of Hazardous Materials, Vol. 171, pp. 29-37.

Aworh, O. C., Hicks, J. R., Minotti, P. L and Lee, C. Y, (1980), "Effects of plant age and nitrogen fertilization on nitrate accumulation and postharvest nitrite accumulation in fresh spinach", Journal of American Society for Horticultural Science, Vol. 105 No. 1, pp. 18-20.

Ayers, R. S. and Westcot, D. W. (1985), Water quality for agriculture, FAO Irrigation and Drainage Paper No. 29, FAO, Rome, Italy, pp. 8-11.

Black, C. A. (1965), Methods of Soil
Analysis, Part 2: Chemical and Microbiological Properties, American Society of Agronomy and Soil Science Society of America, Madison, WI, USA, pp. 894-1372.

Brady, N. C. and WEIL R. R. (1996), The nature and properties of soils, Prentice Hall Inc., New Jersey, USA, pp. 740.

Bray, R. H. and Kurtz, L. T. (1945), "Determination of total organic and available forms of phosphorus in soils", Journal of Soil Science, Vol. 59, pp. 3945.

Brunner, P. H. and Wasmer, H. R. (1978), Methods of analysis of sewage sludge solid wastes and compost, International Reference Center for Wastes Disposal (H8600), World health organization, Dulendrof, Switzerland.

Chapman, H. D. and Pratt, P. F. (1978), Methods of analysis for soils, plants and water, University of California, Division of Agriculture Science, USA.

Cottenie, A., Verloo, M., Kikens, L., Velghe, G. and Camerlynck, R. (1982), Analytical problems and methods in chemical plant and soil analysis, Cottenie A. Ed., Gent, Belgium.

Diaz, 1. F., Bertoldi, D. E. M. and Bidlingmaier, W. (2007), Compost science and technology, Elsevier Science, Boston, USA, pp. 364. 
El-Fayoumy, M. E., Ramadan, H. M., Kandil, N. F., AbuSinna, M. A. and Hassanien, S. A. (2000), "Nitrogen Losses in Water Table From Successive uses of N-fertilizer", Alexandria Science Exchange Journal, Vol.21 No.4, pp.443-466.

El-rashidi, M. A., L. T. West, C. A. Seybold, E. C. Benham, P. J. Schoeneberger and Ferguson, R. (2010). Effects of gypsum addition on solubility of nutrients in soil amended with peat", Journal of Soil Science, Vol. 175 No. 4, pp. 162172.

Ersahin, S. and Rustu, K. M. (2001), "Estimating potential nitrate leaching in nitrogen fertilizer and irrigated tomato using the computer model NLEAP", Agricultural Water Management, Vol. 5, pp. 1-12.

Galloway, J. N. and Cowling, E. B. (2002), "Reactive nitrogen and the world: 200 years of change", A Journal of the Human Environment, Vol. 31 No. 2, pp. 64.

Garwood, T. W. S., Sdavies, D. B., and Hartly, A. R. (1999), "The effect of winter cover crops on yield at the following spring crops and nitrogen balance in a calcareous loam soil", Journal of Agricultural Science, Vol. 132, No. 1, pp.1-11.

Guadagnin, S., Rath, S. and Reyes, R. (2005), "Evaluation of the nitrate content in leaf vegetables produced through different agricultural systems", Food Additives

Contaminants, Vol. 22, pp. 12031208.

Harrison, R. M. and Chirgawi, M. B. (1989), "The assessment of air and soil as contributors of some trace metals to vegetable plants I. Use of a filtered air growth cabinet", Science of the Total Environment Journal, Vol. 83, pp. 13-34.

He, Y. and Li, R. (2004), "Effect of the organo-inorgano-mixed fertilizer application on sugarcane yield and soil enzymatic activity", Sugar Crops China, Vol. 4, pp. 36-38.

Hunt, J. and Turner, M. K. (1994), "A survey of nitrite concentrations in retail fresh", Journal of Environmental Management, Vol. 86, pp. 272-281.

Jackson, M. L. (1967), Soil Chemical Analysis, Prentice Hall of Englewood cliffs, New Jersey, USA.

Jakub, E., Lukas P., Antonín K., Jitka P., Jaroslav, Z. and Jürgen, K. F. (2014), "The effect of increased doses of compost on leaching of mineral nitrogen from arable land pol", Polish Journal of Environmental Studies, Vol. 23 No. 3, 697-703.

Kaiser, M. F. (2009), "Environmental changes remote sensing, and infrastructure development: The case of Egypt's East Port Said harbor", Applied Geography 
Journal, Vol. 29, pp. 280-288.

Koo, B. K. and Connell, P. E. (2006), "An integrated modelling and multicriteria analysis approach to managing nitrate diffuse pollution: 1. Framework and methodology", Science of the Total Environment, Vol. 359 No. 1-3, pp. 1-16.

Laftouhi, N., Vanclooster, M., Jalal M., Witam O., Aboufirassi M., Bahir, M. and Persoons, E. (2003), "Groundwater nitrate pollution in the Essaouira Basin (Morocco)", Comptes Rendus Geosciences, Vol. 335, pp. 307-317.

Lokeshwari, H. and Chandrappa, G. T. (2006), "Impact of heavy metal contamination of Bellandur Lake on soil and cultivated vegetation", Current Science, Vol. 91 No. 5, pp. $622-627$.

Marco, A., Huez-López1., April, L. U., Zohrab, S., Picchioni, G. and Flynn, R. P. (2011), "Response of chile pepper (Capsicum annuum L.) to salt stress and organic and inorganic nitrogen sources: ii. Nitrogen and water use efficiencies, and salt tolerance", Tropical and Subtropical Agroecosystems, Vol. 14, pp. 757763.

Masetti, M., Poli, S., Sterlacchini, S., Beretta, G.P. and Facchi, A. (2008), "Spatial and statistical assessment of factors influencing nitrate contamination in groundwater", Journal of Environmental
Management, Vol. 86 No. 1, pp. 272- 281.

Mensinga, T. T., Speijers, G. J. and Meulenbelt, J. (2003), "Health implications of exposure to environmental nitrogenous compounds", Toxicological Reviews, Vol. 22 No. 1, pp. 41-51.

Mohammad, J. K. h., Mohammad, T. J. U., Amin, K. h., Mohammad, A. and Mohammad, S. (2010), "Management of saline sodic soils through cultural practices and gypsum", Pakistan Journal of Botany, Vol. 42 No. 6, pp. 41434155.

Naceur, J. and Chedly, A. (2009), "Effectiveness of compost use in salt-affected soil", Journal of Hazardous Materials, Vol. 171, pp. 29-37.

Nelson J. L., Kurtz, L. T. and Bray, R. H. (1954). Rapid determination of nitrates and nitrites", Analytical Chemistry journal, Vol. 26, pp. 1081- 1082.

Page, A. L, Miller, R. H. and Keeney, D. R. (1982), Methods of Chemical Analysis, Part 2: Chemical and Microbiological Properties (Second Edition), American Society of Agronomy and Soil Science Society of America, Madison, Wisconsin, USA.

Pentecost, A. (1999), "Testing if a relationship occurs between two 
variables using correlation", Analysing environmental data, Pearson Education Limited, England, pp. 102-106.

Piper, C. S. (1950), Soil and Plants analysis, A monograph from the water, Agricultural Research Institute, University of Alelaide, Australia.

Plošek L., Elbl J., Kintl A., Záhora J., Hynšt J. (2013), "Influence of added compost on leakage of mineral nitrogen and biomass production", Waste forum, Vol. 2013 No. 1, pp. 20-28.

Raiswell, R. W. and Liss, P. S. (1982), "Environmental chemistry: the earth-air-water factory", Endeavour, Vol. 6 No. 2, pp. $66-71$.

Robert, P. C. (2002), "Precision agriculture a challenge for crop nutrition management", Plant and Soil, Vol. 247, pp. 143-149.

Santamaria, P. (2006), "Nitrate in Vegetables: toxicity content, intake and European commission regulation", Journal of Science and Food Agronomy, Vol. 86, pp. 1017.

Simek, M., Jisova, L. and Hopkins, D. W, (2002), "What is the socalled optimum $\mathrm{pH}$ for denitrification in soil", Soil Biology and Biochemistry Journal, Vol. 34 No. 9, pp. 1227.

Sina, S., Mahmoud, S., Abdollah, S.,
Alireza, A. S. and Jahangir, A. (2012), "Effect of nitrogen fertilizers on nitrate leaching from a saline soil profile under corn and barley cultivation", International Research Journal of Applied and Basic Sciences, Vol., 3 No. 3, pp. $563-$ 567.

Snedecor, G. W. and Corharn, W. G. (1979), Statistical Methods, Iowa State University Press, Ames, Iowa, USA, pp. 593.

Socolow, R. H. (1999), "Nitrogen management and the future of food: Lessons from the management of energy and carbon", Proceedings of the National Academy of Sciences of the United States of America, Vol. 96 No 11, pp. 6001-6008.

Suge, J. K, Omunyin., M. E. and Omami, E.N. (2011), "Effect of organic and inorganic sources of fertilizer on growth, yield and fruit quality of eggplant (Solanum melongena L)", Archives of Applied Science Research, Vol. 3 No. 6, pp. 470479.

Tamme, T., Reinik, M. and Roasto, M. (2009), "Nitrates and Nitrites in Vegetables: Occurrence and Health Risks", In: Watson R. R., Preedy V. R. (ED), Bioactive Foods Promoting Health: Fruits and Vegetables, Academic Press, Salt Lake City, UT, USA, pp. 307-321.

Tejada M., Garcia, C., Gonzalez, J. L. and Hernandez, M. T. (2006), "Use 
of organic amendment as a strategy for saline soil remediation: Influence on the physical, chemical and biological properties of soil", Journal of Soil Biology and Biochemistry, Vol. 38, pp. 1413421 .

Tripathy, P. and Maity, T. K. (2011), "Evaluation of Kharif Okra hybrids under reduced level of chemical fertilizers", Orissa Journal of Horticulture, Vol. 36 No. 1, pp. 1-7.

U. S. Agency for Toxic Substances and Diseases Registry (2017). "Case Studies in Environmental Medicine: Nitrate/ Nitrite Toxicity", available at:

https://www.atsdr.cdc.gov/csem/nitr ate_2013/docs/nitrite.pdf .

U. S. Environmental Protection Agency Pesticides and Toxic Substances (1991), "R.E.D. Facts: Inorganic Nitrates/Nitrite (Sodium and Potassium Nitrates)", Food Additives and Contaminants, Vol. 11 No. 3, pp. 327-332.

Villa-Castorena, M., Ulery, A. L., Catalan-Valencia, E. A. and Remmenga, M. (2003), "Salinity and nitrogen rate effects on the growth and yield of Chile pepper plants", Soil Science Society of American Journal, Vol. 67, pp. 1781-1789.

Voorhees, M. E. and Uresk, D. W. (1990), "Effect of Amendments on chemical properties of Bentonite Mine Spoil", Journal of Soil
Science, Vol. 150 No. 4, pp. 663775 .

Wolf, J., Roetter, R. and Oenema, O. (2005), "Nutrient emission models in environmental policy evaluation at different scales-experience from the Netherlands", Agriculture Ecosystems and Environment, Vol. 105, pp. 291-306.

World Health Organization (2006), "International Program on Chemical Safety, Environmental Health Criteria 5: Nitrates, Nitrites, and NNitroso Compounds", available at: http://www.inchem.org/documents/p ims/chemical/pimg016.htm.

Zaka, M. A., Mujeeb, F., Sarwar, G., Hassan, N. M. and Hassan, G. (2003), "Agro- melioration of saline sodic soil", OnLine Journal of Biological Sciences, Vol. 3, pp. 329-334.

Zebarth, B. J., Drury, C. F., Tremblay, N. and Cambouris, A. N. (2009), "Opportunities for improved fertilizer nitrogen management in production of arable crops in eastern Canada: A review", Canadian Journal of Soil Science, Vol. 89, pp. 113-132. 